REVIEW ARTICLE

\title{
Evaluation of Mental Foramen Location - A Review Article
}

Hussein Haleem Jasim*

${ }^{1}$ Department of Oral Diagnosis, College of Dentistry - University of Wasit
The aim of study: The point of the think about: To assess the site of the mental foramen in relative to the mandibular premolars, depended on the panoramic and CBCT and O.P.G images.

Materials and Methods: The current study involved the previous articles published from 1997 till 2019, with respect to the site of mental foramen in elderly and adult patients, in any case of the gender. All these studies were used on either the panoramic and cone-beam computed tomographic images for visualizing the site of the mental foramen.

Results: Regarding the outcomes of the previous studies included in this review, the statistics appeared that the first common area of mental foramen was beneath the apices of lower second premolars in the percentage of $49.99 \%$, the other second common area of mental foramen was between the apices of the lower first and second premolars in the percentage of $42.30 \%$.

Conclusion: The mental foramen was mostly found beneath the apices of lower first and second premolars and then between the apices of the lower first and second premolars.

Keywords: Mental foramen, Mental nerve, Mandible, Mental artery, Mandibular canal, Inferior alveolar canal. 


\section{1 | INTRODUCTION:}

$\mathrm{M}$ ental foramen founded as a funnel like orifice represent the hole of the mandibular canal existing on both sides of mandible. The mental nerve is involved in this canal and emerged from on this orifice. The mental artery exits in conjunction with the mental nerve, this artery represents a branch of the inferior alveolar artery. ${ }^{[1][2]}$ These neuro-vascular complex give the supply to gingiva in area following to the premolars as well as give supply to alveolar mucosa, lower lip and the skin of chin .

High safety measures must be involved via practicing of dental surgery to evade harming of these imperative structures by utilizing the appropriate imaging techniques ${ }^{[3][4]}$ Harming of the mental nerve via the dental procedure or due to other causes will lead to defects in the lower lip sensation, in addition, the surrounding skin and soft tissues. ${ }^{[5],[6]}$ Mental foramen also showed wide anatomical varieties including the site, size and shape of the mental foramen. ${ }^{[7-9]}$

The site of mental foramen was mostly either under the apices of mandibular $2^{\text {nd }}$ premolars, ${ }^{[10][11][12]}$ or between the apices of mandibular $1^{\text {st }}$ and $2^{\text {nd }}$ premolars. ${ }^{[13]}$ But on the other hand, numerous varieties with respect to the site of mental foramen were reported.

Different conditions are affected on the site of the mental foramen directly as age, gender, loss of teeth, race and bone resorption. ${ }^{[14]}$

The exact identification of the mental foramen area still even now the most common challenging for many dentist arranging to operate on or close the mental foramen. Different imaging procedures utilized to identify the site of mental foramen as "Panoramic radiograph O.P.G, Periapical radiograph, Computed tomography (CT), Magnetic Resonance Imaging (MRI) and Cone-Beam Computed Tomography(CBCT)". ${ }^{[15]}$ Panoramic radiographs have restriction on visualizing of the MF area, particularly within the buccolingual measurement as well as, horizontal and vertical planes magnification. CT shows great changes within the visualization of location and anatomy of dental structures. ${ }^{[16]}$
These days, CBCT considered the foremost exact imaging innovation that utilized to identify the exact location of the mental foramen, and the route of the mental nerve through the mandibular canal canal. ${ }^{[17]}$

\section{2 | MATERIALS AND METHODS:}

The current study involved the previous articles published which were achieved in deferent areas of the world, from 1997 till 2019, with respect to the site of mental foramen in elderly and adult patients, in any case of the gender. All these studies were used on either the panoramic and cone-beam computed tomographic images for visualizing the site of the mental foramen to assess the site of the mental foramen in relative to the mandibular premolars. Table 1.

\section{3 | RESULTS:}

The statistics of the reviewed studies included in this review appeared that the first common area of mental foramen was beneath the apices of lower second premolars in the percentage of $49.99 \%$, the other second common area of mental foramen was between the apices of the lower first and second premolars in the percentage of $42.30 \%$, and the next location was at the line of apices of the lower second premolars in the percentage of $4.11 \%$, the next area after that was between the lower second premolars and the lower first molar in the percentage of $3.84 \%$ , in addition to a very small proportion was slightly up to the apices of lower second premolars.

Supplementary information The online version of this article (https://doi.org/10.15520/mcrr.v3i7.107) contains supplementary material, which is available to authorized users.

Corresponding Author: Hussein Haleem Jasim Department of Oral Diagnosis, College of Dentistry University of Wasit 
EVALUATION OF MENTAL FORAMEN LOCATION - A REVIEW ARTICLE

TABLE 1: Locationof Mentalforamen regarding the different previous studies in different populace.

\begin{tabular}{|c|c|}
\hline Population & Site \\
\hline Byzantiums, $1997^{3 y]}$ & $\begin{array}{l}\text { 1. Between lower right premolars. } \\
\text { 2. In a line along the lower left quat premolars. }\end{array}$ \\
\hline Zimbabweans, $1998^{[4]}$ & $\begin{array}{l}\text { 1. Beneath the lower right } 2^{2 \mathrm{w}} \text { premolars. } \\
\text { 2. Between the lower left } 2^{\mathrm{wh}} \text { premolars and left first molars. }\end{array}$ \\
\hline Caucasians, 2004 $4^{[1]}$ & Between lower premolars. \\
\hline Malawians, 2005:[4] & $\begin{array}{l}\text { The perpendicular level of mental foramen was frequently situated approximately beneath the mid- } \\
\text { route between the alveolar edge and the lower border of lower jaw. }\end{array}$ \\
\hline Tanzanians, 2007/[4] & 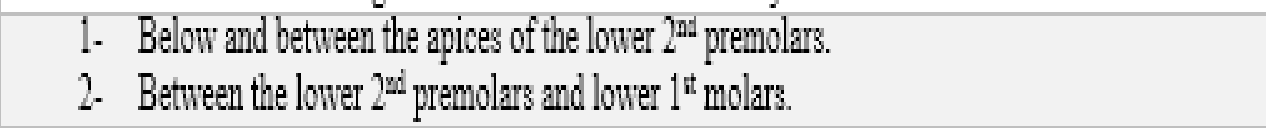 \\
\hline Jordanians, 2007 $7^{[4]}$ & Below and between the lower premolars. \\
\hline Sri Lankans, 2009:[4] & $\begin{array}{l}\text { 1. In a level along the long axis of the lower } 2 \text { wid premolars. } \\
\text { 2. Between lower premolars. }\end{array}$ \\
\hline Japanese, 2009:4] & 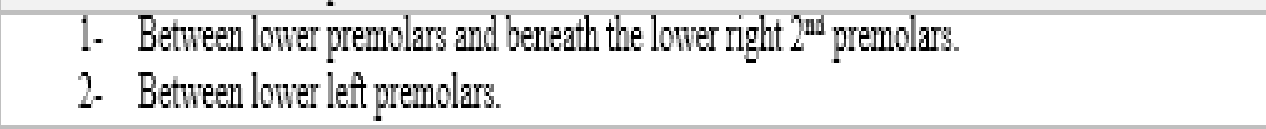 \\
\hline Iraqu, 2010 [4] & Below the apices of the lower 2 nd premolars. \\
\hline Nigerian, 2012:4] & In a level of the apices of lower 2 in premolars. \\
\hline Turkish, 2013/45 & $\begin{array}{l}\text { 1. In a level along the long axis of the lower } 2 \text { premolars. } \\
\text { 2. Between lower premolars. }\end{array}$ \\
\hline Chinese, $2015^{[5]}$ & In a level along the long axis of the lower $2^{\text {mid }}$ premolars. \\
\hline Indian, $2015^{[4]}$ & $\begin{array}{l}\text { 1. Between lower premolars. } \\
\text { 2. In in the plane along the lower } 2^{\text {ud }} \text { premolars. }\end{array}$ \\
\hline $\begin{array}{l}\text { Brazilian, 2015 } \\
\text { Iranian, } 2016^{[4]}\end{array}$ & $\begin{array}{l}\text { In a level along the long axis of apices for the lower } 2^{\text {nt }} \text { premolars. } \\
\text { 1. The mental foramen (in a horizontal level) placed on a level with the lower } 2^{\text {mas }} \text { premolars. } \\
\text { 2. Between lower premolars. }\end{array}$ \\
\hline UK, 2016!:20] & Between lower premolars. \\
\hline Indian, 2017[1] & Beneath the apices of the lower $2 \mathrm{~m}$ premolars. \\
\hline Saudi, 2017:[2] & $\begin{array}{l}\text { 1. Beneath the apices of lower } 2^{\text {nal }} \text { premolars. } \\
\text { 2. Beneath lower premolars. }\end{array}$ \\
\hline Belarusian, 2017 $7^{[x]}$ & Between lower premolars. \\
\hline Serbian, $2017^{7: 4]}$ & Beneath the apices of the lower $2^{2 n}$ premolars and mesially directed. \\
\hline Brazilian, 2017!: & Near the apices of the lower $2^{m i}$ premolars. \\
\hline Saudi, 2017::8] & $\begin{array}{l}\text { 1. Between the lower premolars. } \\
\text { 2. Beneath the apices of lower } 2 \text { at premolars. }\end{array}$ \\
\hline $\begin{array}{l}\text { Turkish, 2008[3] } \\
\text { Indian, 2018: }\end{array}$ & $\begin{array}{l}\text { In a level along the long axis of the lower } 2 \text { nd premolars. } \\
\text { Beneath the apices of the lower } 2^{\text {2n }} \text { premolars }\end{array}$ \\
\hline Saudi, $2018^{[: x]}$ & $\begin{array}{l}\text { 1. In a level along the long axis of the lower } 2 \text { nd premolars. } \\
\text { 2. In a line with the long axis of lower } 1^{1 t} \text { premolar. }\end{array}$ \\
\hline Polish, 2019[::"] & $\begin{array}{l}\text { 1. } \quad \text { Beneath the apices of lower } 2^{\text {nat }} \text { premolars. } \\
\text { 2. } \quad \text { In the apical level of lower } 2^{\text {sid }} \text { premolars. }\end{array}$ \\
\hline Pakistanian, 2019.00] & $\begin{array}{l}\text { 1. Beneath the apices of lower } 1^{\mathrm{t}} \text { premolars. } \\
\text { 2. Beneath the lower } 2^{2 \mathrm{~s}} \text { premolars. }\end{array}$ \\
\hline
\end{tabular}




\section{4 | DISCUSSION :}

Many researchers have centered on the status of the mental foramen. Their studies have focused according to the location, shape and dimensions of mental foramen and many variations have been found in this respect. In clinical practice, The anatomical site of the mental foramen play a very significant role, so the dentist operate on or close this foramen must take into the regard the site of this foramen since any harm to the neurovascular complex emitting from the foramen may lead to transitory or persistent loss of sensation in the supplied area by this complex depending on the seriousness of the harm. Subsequently, knowing the exact anatomical site of the mental foramen maybe effective step to avoid any damage to this vital structure during dental operation close to or on the mental foramen.

For instance, the anesthesia of mental nerve block elevates the chance of hitting the crucial structures within the mental foramen. In addition, during the endodontic treatment of mandibular premolars, the threat of harm to the mental nerve is very possible, particularly within the individuals with the area of the foramen close or straightforwardly on the apices of the lower premolars, especially lower 2nd premolars. The dental implants placed at the area of the premolars have also a really critical circumstance due to the presence of mental foramen, the same thought must be taken when planning the surgical flap on or close this foramen. So, the radiographic assessment of mental foramen is very important before any action in or close this foramen.

Various imaging advances utilized to imagine the mental foramen as panoramic radiography, periapical radiography, computed tomography and conebeam computed tomography. The last two innovations considered the most exact imaging technologies compared to the other innovations. Cone-beam computed tomography enhancing the imaging of the dento-maxillofacial structures, so it gives more accurate picture in these areas than in computed tomography.

Researches of mental foramen had reported extensive varieties with respect to the race, gender and age. ${ }^{[18]}$ For instance, within the Caucasian populace the mental foramen was located between lower 1st and 2nd premolars. ${ }^{[7]}$ Whereas within the Mongoloids populace was located near to the apices of lower 2nd premolars. ${ }^{[19][20]}$

The reviewed results in this current review with respect to the site of the mental foramen and they were showed that the most location of mental foramen is beneath the apices of lower 2 nd premolars (in the rate of $44.99 \%$ ), In most populace of Iraq, India and Korea found the most site of mental foramen was beneath the apices of the lower 1 st and 2 nd premolars or $1 \mathrm{st}$ molars in the percentages of $60.1 \%$, $72.2 \%$ and $62.5 \%$, respectively. ${ }^{[21][22][23]}$ The site of mental foramen was commonly distinguished along a line at the long axis of the lower 2 nd premolars in Saudi ${ }^{[13],}$ Kenyan $^{[24],}$ Nigerian $^{[25]}$, Sir Lankan ${ }^{[26]}$, Chinese $^{[27][28]}$ Figure 1.
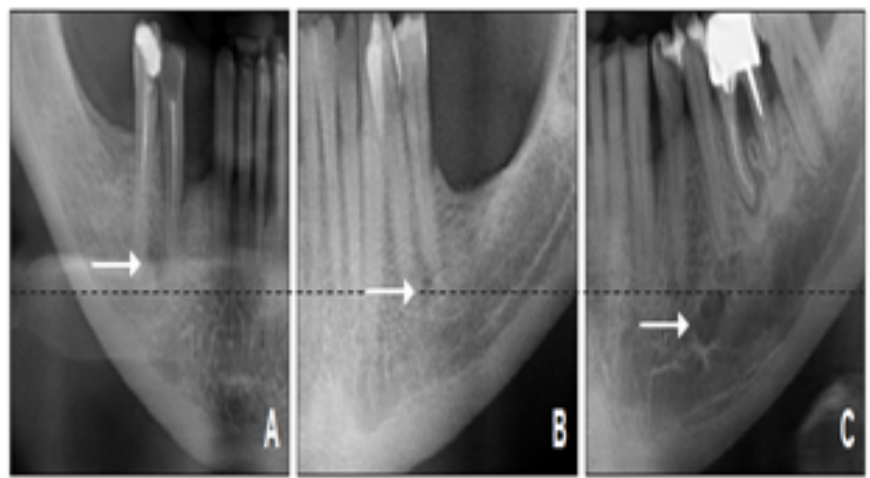

FIGURE 1: Different panoramic images (O.P.Gs) showing thesite of the mental foramen in theperpendicular line in relative to apicesof premolars; (white arrows). A- Coronal to the apex; B- At the apex; C- Apicalto the apex. ${ }^{[61][62]}$

The most next site of mental foramen in the current review was between the apices of the lower $1 \mathrm{st}$ and 2 nd premolars (in the rate of $42.30 \%$ ). Several researches have registered that the most common site of the mental foramen was between the lower premolars based on O.P.G. ${ }^{[29][30][31]}$ and CBCT..$^{[32][33]}$ Researches achieved in the population of Turkey and Asia appeared the site of mental foramen was between the lower premolars (in the rates of $71.50 \%$ and $63 \%$ ), respectively. ${ }^{[34][31]}$

The differentiation of mental foramen regarding the location may be due to racial variation within the populaces. This is compatible with the Green's result. ${ }^{[35]}$ The variety regarding the site of mental 
foramen was also conducted to be hereditarily as a result of the rising of mandibular measure along the development period. ${ }^{[36]}$ Natural variables as propensities of eating or alteration within the nature of food. ${ }^{[37][38]}$ and muscles dystrophy. ${ }^{[37]}$ All these circumstances had attributed to influence the site of mental foramen.

Figure 1. Different panoramic images (O.P.Gs) showing the site of the mental foramen in the perpendicular line in relative to apices of premolars; (white arrows). A- Coronal to the apex; B- At the apex; CApical to the apex. ${ }^{[61][62]}$

\section{5 | CONCLUSION:}

The mental foramen was mostly found beneath the apices of lower first and second premolars and then between the apices of the lower first and second premolars.

\section{I REFERENCES:}

1. Montagu MF. The direction and position of the mental foramen in the great apes and man. Am.J.Phys.Anthropol. 1954 Dec;12(4):503-518.

2. De Freitas V, Madeira MC, Pinto CT, Zorzetto NL. Direction of the mental canal in human mandibles. Aust.Dent.J. 1976 Aug;21(4):338-340.

3. Kim IS, Kim SG, Kim YK, Kim JD. Position of the mental foramen in a Korean population: a clinical and radiographic study. Implant Dent. 2006 Dec;15(4):404-11.

4. Rueda S, Gil JA, Pichery R, Alcañiz M. Automatic segmentation of jaw tissues in CT using active appearance models and semi-automatic landmarking. Med Image Comput Comput Assist Interv. 2006;9(Pt 1):167-74.

5. Greenstein, G., Tarnow, D., 2006. The mental foramen and nerve: clinical and anatomical factors related to dental implant placement: a literature review. J. Periodontol. 77 (12), 1933-1943.

6. Ritter, L., Neugebauer, J., Mischkowski, R.A., Dreiseidler, T., Rothamel, D., Richter, U., Zinser,
M.J., Zo“1ler, J.E., 2012.Evaluation of the course of the inferior alveolar nerve in the mental foramen by cone beam computed tomography. Int. J. Oral Maxillofac. Implants 27 (5).

7. Neiva RF, Gapski R, Wang HL. Morphometric analysis of implant-related anatomy in Caucasian skulls. J Periodontol. 2004 Aug;75(8):1061- 1067.

8. Apinhasmit W, Chompoopong S, Methathrathip D, Sansuk R, Phetphunphiphat W. Supraorbital Notch/Foramen, Infraorbital Foramen and Mental Foramen in Thais: anthropometric measurements and surgical relevance. J Med Assoc Thai. 2006 May;89(5):675-82.

9. Gershenson A, Nathan H, Luchansky E. Mental foramen and mental nerve: changes with age. Acta Anat (Basel). 1986;126(1):21-8.

10. Philips, J.L., Weller, R.N., Kulild, J.C., 1992. The mental foramen: Part II. Radiographic position in relation to the mandibular second premolar. J. Endodontics 18 (6), 271-274.

11. Shankland 2nd, W.E., 1994. The position of the mental foramen in Asian Indians. J. Oral Implantol. 20 (2), 118-123.

12. Fabian, F.M., 2007. Position, shape and direction of opening of the mental foramen in dry mandibles of Tanzanian adult black males. Ital. J. Anat. Embryol. 112 (3), 169-177.

13. Al Jasser, N.M., Nwoku, A.L., 1998. Radiographic study of the mental foramen in a selected Saudi population. Dentomaxillo. Radiol. 27 (6), 341-343.

14. Igbigbi, P.S., Lebona, S., 2005. The position and dimensions of the mental foramen in adult Malawian mandibles. West Afr. J. Med.24 (3), 184-189.

15. Aminoshariae, A., Su, A., Kulild, J.C., 2014. Determination of the location of the mental foramen: a critical review. J. Endodontics 40 (4), 471-475.

16. Bou Serhal C, Jacobs R, Flygare L, Quirynen $M$, van Steenberghe D. Perioperative validation of localisation of the mental foramen. Dentomaxillofac Radiol. 2002;31(1):39-43.

17. Vujanovic-Eskenazi, A., Valero-James, J.M., Sa'nchez-Garce's, M.A., Gay-Escoda, C., 2015. A retrospective radiographic evaluation of the ante- 
rior loop of the mental nerve: comparison between panoramic radiography and cone beam computerized tomography. Medicina oral, patologia oral y cirugia bucal 20 (2), e239.

18. Lipski M, Tomaszewska IM, Lipska W et al. The mandible and its foramen: anatomy, anthropology, embryology and resulting clinical implications. Folia. Morphol. (Wartsz). 72, 285-292 (2013).

19. Hasan T. Characteristics of the mental foramen in different populations. The. Internet. Journal. of. Biological. Anthropology. 4, 1-7 (2010).

20 . Ngeow WC, Yuzawati Y. The location of the mental foramen in a selected Malay population. J. Oral. Sci. 45, 171-175 (2003).

21 . Parnami P, Gupta D, Arora V, et al. Assessment of the horizontal and vertical position of mental foramen in indian population in terms of age and sex in dentate subjects by panoramic radiographs: a retrospective study with review of literature. Open. Dent. J. 9, 297-302. (2015).

22 . Muhsen SJ. Horizontal and vertical position of the mental foramen on panoramic views of a selected Iraqi population. Journal. of. Baghdad. college. of. dentistry. 23, 69-72 (2011).

23 . Fishel D, Buchner A, Hershkowith A, Kaffe I. Roentgenologic study of the mental foramen. Oral Surg Oral Med Oral Pathol. 1976 May;41(5):682-6.

24 . Mwaniki DL, Hassanali J (1992) The position of mandibular and mental foramina in Kenyan African mandibles. East Afr Med J 69: 210-213.

25 . Kekere-Ekun TA (1989) Antero-posterior location of the mental foramen in Nigerians. Afr Dent J 3: $2-8$.

26 . Ilayperuma I, Nanayakkara G, Palahepitiya N (2009) Morphometric analysis of the mental foramen in adult Sri Lankan mandibles. Int J Morphol 27: 1019-1024.

27 . Santini A, Land M (1990) A comparison of the position of the mental foramen in Chinese and British mandibles. Acta Anat (Basel) 137: 208-212.

28 . Wang TM, Shih C, Liu JC, Kuo KJ (1986) A clinical and anatomical study of the location of the mental foramen in adult Chinese mandibles. Acta Anat (Basel) 126: 29-33.
29 . Kqiku L, Sivic E, Weiglein A, Städtler P. Position of the mental foramen: an anatomical study. Wien Med Wochenschr. 2011 May;161(9-10):2723.

30 . Pria CM, Masood F, Beckerley JM, Carson RE. Study of the inferior alveolar canal and mental foramen on digital panoramic images. J Contemp Dent Pract. 2011 July-Aug;12(4):265-71.

31 . Gada SK, Nagda SJ. Assessment of position and bilateral symmetry of occurrence of mental foramen in dentate asian population. J Clin Diagn Res. 2014 Feb;8(2):203-5.

32 . Von Arx T, Friedli M, Sendi P, Lozanoff $\mathrm{S}$, Bornstein MM. Location and dimensions of the mental foramen: a radiographic analysis by using cone-beam computed tomography. J Endod. 2013 Dec;39(12):1522-8.

3 3. Kalender A, Orhan K, Aksoy U. Evaluation of the mental foramen and accessory mental foramen in Turkish patients using cone-beam computed tomography images reconstructed from a volumetric rendering program. Clin Anat. 2012 July;25(5):58492.

34 . Gungor K, Ozturk M, Semiz M, Brooks SL. A radiographic study of location of mental foramen in a selected Turkish population on panoramic radiograph. Coll Anthropol. 2006;30:801-5.

35 . Green RM (1987) The position of the mental foramen: a comparison between the southern (Hong Kong) Chinese and other ethnic and racial groups. Oral Surg Oral Med Oral Pathol 63: 287-290

36 . Renaud S, Auffray JC, de la Porte S. Epigenetic effects on the mouse mandible: common features and discrepancies in remodeling due to muscular dystrophy and response to food consistency. BMC. Evol. Biol. 10, 28. (2010).

37 . Yeşilyurt H, Aydinlioglu A, Kavakli A, et al. Local differences in the position of the mental foramen. Folia Morphol (Warsz). 2008;67(1):32-35.

38 . Siddiqui AU, Daimi SR, Mishra PP, et al. Morphological and morphometric analysis of mental foramen utilizing various assessment parameters in dry human mandibles. Int. J. Stud. Res. 1, 19-22 (2011). 
39. Ikiz T, Erem. Relation of the mental foramen to teeth on the mandibles belonging to the Byzantium period. International journal of anthropology.1997;12:1-4.

40. Mbajiorgu EF, Mawera G, Asala SA, Zivanovic S. Position of the mental foramen in adult black Zimbabwean mandibles: a clinical anatomical study. Cent Afr J Med.1998;44:24-30.

41. Taiseer AK,Abed AH, Hamasha KTA. Position of the mental foramen in a northern regional Jordanian population. Surgical and radiologic anatomy.2007;29(3): 231-237.

42. Oliveria J E M, Arajo, A. L. D, SilvaC. M. F,Sousa R C F, Lima FJC. Morphologicaland morphometric study of the mental foramen on the MCP-18 jiachenjiang point. Int. J. Morphol. 2009; 27(1):231-238.

43. Luay N. Kaka, Amal R S. Mohammed, Fatin Kh. Abbas. Estimation of the position of mental foramen and its relation to lower premolars and base border of the mandible during aging. J Bagh College Dentistry.2010;22(3):65-68.

44. S.A. Adejuwon, Femi- Akinlosotu, M. Omowunmi and O.T. Salawu, 2012. Variations in the Mandibular Foramina of Yoruba Ethnic Group of Nigeria. Journal of Medical Sciences, 12: 188192.

45. Sekerci AE, Sahman H, Sisman Y, Aksu Y. Morphometric analysis of the mental foramen in a Turkish population based on multi-slice computed tomography. J Oral Maxillofac Radiol 2013;1:2-7.

46. Zhang L, Zheng Q, Zhou X, Lu Y, Huang D (2015) Anatomic Relationship between Mental Foramen and Peripheral Structures Observed By ConeBeam Computed Tomography. Anat Physiol 5: 182.

47. Medha Babshet, Sandeep R, Krishna Burde, and Kirty Nandimath, "Evaluation of the Position of Mental Foramen and Its Correlation with Age in Selected Indian Population, Using Digital Panoramic Radiograph." International Journal of Dental Sciences and Research, vol. 3, no. 4 (2015): 87-91.

48. Saito, Kunihiro, Araújo, Ney Soares de, Saito, Miki Taketomi, Pinheiro, João de Jesus Viana, \& Carvalho, Pedro Luiz de. (2015). Analysis of the mental foramen using cone beam computerized tomography. Revista de Odontologia da UNESP, 44(4), 226-231.

49. Soheilifar S, Bidgoli M, Shokri A, Faradmal J, Kafilzadeh S, Eyvazi P, et al. Panoramic radiographic study of mandibular canal and mental foramen in a selected Iranian population. SRM J Res Dent Sci 2016;7:209-13.

50. Currie CC, Meechan JG, Whitworth JM, Carr A, Corbett IP. Determination of the mental foramen position in dental radiographs in 18-30 year olds. Dentomaxillofac Radiol. 2016;45(1):20150195.

51. Srivastava S, Patil RK, Tripathi A, Khanna V, Sharna P (2017) Evaluation of Mental Foramen in U. P. Population- A CBCT Study. J Otolaryngol ENT Res 8(4): 00253.

52.. Al-Mahalawy H, Al-Aithan H, Al-Kari B, AlJandan B, Shujaat S. Determination of the position of mental foramen and frequency of anterior loop in Saudi population. A retrospective CBCT study. Saudi Dent J. 2017;29(1):29-35.

53. SL Kabak, NV Zhuravleva, YM Melnichenko, N Alex. Topography of mental foramen in a selected Belarusian population according to cone beam computed tomography. Imaging in Medicine 9 (3), 49-58

54. Jelena Popović, Marija Daković Bjelaković, Jovanka Gašić, Milan Spasić, Marija Nikolić, Radomir Barac. The mental foramen position in relation to the radiographic apex of the mandibular second premolar. Rad. Applic., 2017, 2, 1, 26-30

55. Pasquali, J. G., Narazaki, N. D., Franco, A., Vieira, I., Fernandes, Â., \& de Lima, A. A. Assessing the Radiographic Position of the Mental Forament in a Brazillian Population. J Dent Indones. 2017;24(1): 19-22.

56. Muhannad Abdulrhman Mohammed Halwani, Majed Abdullah Ibn Muteq. Radiographic localization of the mental foramen position in King Khalid University dental clinics patients in Abha-Saudi Arabia. IJMDC. 2017; 1(2): 41-45.

57.Bhagat J, Shah D, Fernandes G. Prevalence of the Mental Foramen Location in an Indian Subpopulation: A Retrospective Orthopantomogram Study. Int J Oral Care Res.2018;6(2):89-92.

58. ALRahabi, M. \& Zafar, M. Anatomical variations of mental foramen: a retrospective cross- 
sectional study. Int. J. Morphol.,36(3):1124-1129, 2018.

59. Ewa Zmyslowska-Polakowska, Mateusz Radwanski, Slawomir Ledzion, Michal Leski, Agnieszka Zmyslowska, and Monika LukomskaSzymanska. Evaluation of size and location of a mental foramen in the polish population using conebeam computed tomography. BioMed Research International.2019;p1-8.

60. Khalid M, Manzoor F, Rashid A, Salman S, Khawaja SH Ahmed A. Radiological locations of mental foramen in local population. Ann Pak Inst Med Sci. 2019; 15(3): 114-118.

61. Juodzbalys G, Wang HL, Sabalys G. Anatomy of Mandibular Vital Structures. Part II: Mandibu- lar Incisive Canal, Mental Foramen and Associated Neurovascular Bundles in Relation with Dental Implantology. J Oral Maxillofac Res 2010 (JanMar);1(1):e3

62.Fishel D, Buchner A, Hershkowith A, Kaffe I. Roentgenologic study of the mental foramen. Oral Surg Oral Med Oral Pathol. 1976 May;41(5):682-6.

How to cite this article: Jasim H.H. Evaluation of Mental Foramen Location - A Review Article. Journal of Medical Care Research and Review. 2020;379-385. https://doi.org/ 10.15520/mcrr.v3i7.107 